\title{
INFLUENCE OF GRINDING ON MACHINE PARTS WITH DESIGN NOTCHES
}

\author{
Holesovsky, F., Novak, M. \\ Department of Technology and Material Engineering, Faculty of Production Technology and Management, \\ J.E. Purkyne University in Usti nad Labem. Czech Republic. \\ holesovsky@fvtm.ujep.cz
}

\begin{abstract}
The final shape of machine parts is formed out by means of machining. At the machining the surface rises of definite properties, a given integrity, from these a surface usage comes out in the final machinery. This surface use is put especially its service life and loading capacity. The manufacturing watches the selected elements of the surface integrity for the functionality assurance of the machine parts. The machining influences in a different way the variant components. These are e.g. construction notches - the changeovers of single design components. The selection of a technology method of machining, the cutting tool at the finishing can affect notably both the function and service life of a machine part. The paper deals with the surface integrity at the surface load in machinery. There are the questions of the construction notches and next elements owing to the use of finishing method.
\end{abstract}

Key words: grinding, loading, machine part, integrity, notch

\section{REFERENCES}

[1] Bumbálek, L.: Importance of Surface Structure for the Function of Machined Surface. Manufacturing Technology, vol.1, 2001, pp. $10-15$.

[2] Hashimoto, F., Guo, Y.B., Warren, A.W. Surface Integrity Difference between Hard Turned and Ground Surfaces and Its Impact on Fatigue Life. Annals of the CIRP, vol. 55/1/2006

[3] Holešovský, F. Stanovení zbytkových napětí v povrchu po obrábění. Strojírenská technologie, 3/2006, roč.XI, str. 29-32, ISSN 1211-4162

[4] Holešovský, F. Výzkum a nové poznatky broušení. Strojírenská technologie, roč.X, prosinec 2005, str.5155, ISSN 1211-4162

[5] Holešovský, F., Hrala, M. Přípravek pro upevnění snímače sil na hrotové brusce. Užitný vzor, červen 2007, č.17619

[6] Holešovský, F., Hrala, M., Zelenková, J. Properties of Ground Surfaces and Significance of Grinding Process. Proceedings 4th International Congress ICPM, Kielce, Poland, str.23-27, ISBN 978-83-8890691-6

[7] Holešovský, F., Hrala, M., Zelenková, J. Changes of Ground Surface Properties at Dynamical Loading. Technological Engineering, 2/2007, ISSN 1336-5967

[8] Holešovský,F., Hrala, M. Measurement of Cutting Forces in the Centre Grinder. Manufacturing Technology, vol.5, 2005, ISSN 1213-2489

[9] Mádl, J. - Koutný, V. - Rázek, V. - Stránský, R.: Metoda pro simulaci zkoušek opotřebení slinutých karbidů. Strojírenská technologie. 2004, roč. 9, č. 1, s. 28-32. ISSN 1211-4162.

[10] Mádl, J. - Vrabec, M.: Technologičnost konstrukce z hlediska technologie obrábění. Ústí nad Labem: Ústav techniky a řízení výroby UJEP, 2006. 158 s. ISBN 80-7044-757-5.

[11] Marinescu, D.I., Hitchiner, M. etc. Handbook of Machining with Grinding Wheels. CRC Press, Taylor\&Francis Group, New York

[12] Růžička, M. Computational Fatigue Strength Prediction of Turbine Blade Pin Joint. In: Engineering Mechanics 2007. Praha: Ústav termomechaniky AV ČR, 2007, vol. 1, p. 281-282. ISBN 978-80-87012-062.

[13] Růžička, M. On Critical Plane Fatigue Damage Criterion. In: Summer Workshop of Applied Mechanics 2006. Praha: Fakulta strojní ČVUT, 2006, vol. 1, p. 55-56. ISBN 80-01-03453-4. 
[14] Růžička, M. Search for Multiaxial Fatigue Solution. In: Fatigue 2006 - Delegate Manual. Oxford: Elsevier, 2006, p. 152-153.

[15] Vilček, I. - Mádl, J. Frequency Analysis in Tool Monitoring. Manufacturing Technology. 2003, no. 3, s. $12-$ 16. ISSN 1213-2489.

Above mentioned results were created by means of grant GA CR No.101/09/0504. 